\title{
Pelvic masses in a 13-year-old girl-a (not so) rare diagnosis
}

\author{
Catia Correia, Catarina Pardal, Barbara Ribeiro
}

Department of Gynecology and Obstetrics, Hospital de Braga, Braga, Portugal

\section{Correspondence to} Dr Catia Correia, catia_cor@hotmail.com

Accepted 27 May 2015

\section{DESCRIPTION}

Imperforate hymen is the most common congenital cause of genital outflow obstruction in females, with a reported incidence of $0.014-0.024 \%$ in children. ${ }^{1}$ This abnormality may not be detected until the onset of menses, when haematocolpos causes symptoms due to expanding pelvic masses. Recurrent abdominal and back pains are the most common symptoms, associated with primary amenorrhoea and urinary retention. ${ }^{2} 3$

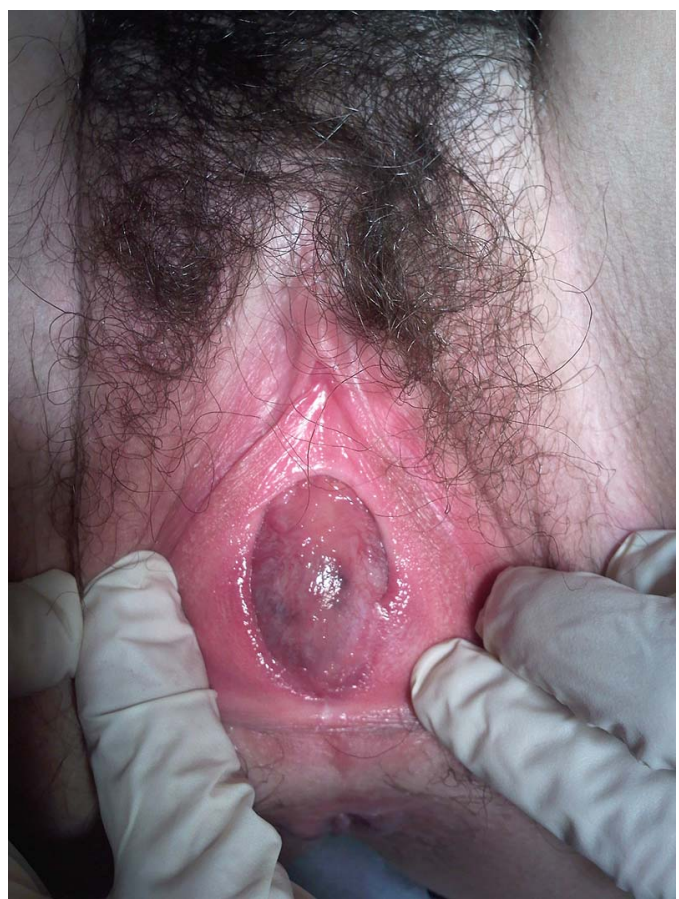

Figure 1 Pelvic inspection showed imperforate hymen that was bulging forwards.

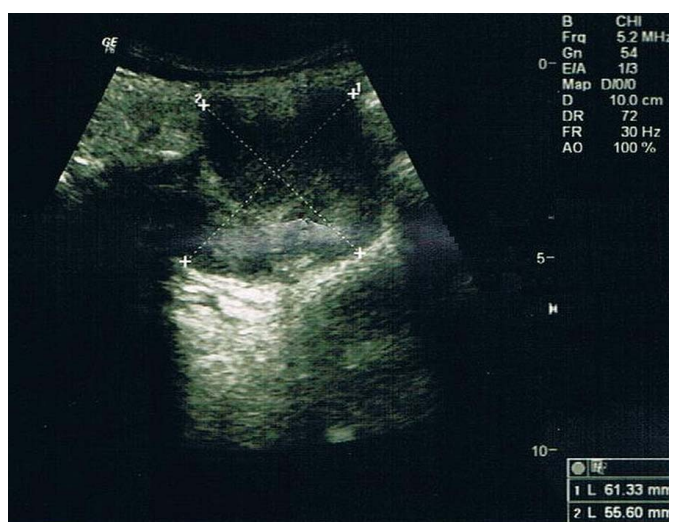

Figure 2 On ultrasound, a dilated uterus was noted, suggestive of haematometra.

A 13-year-old girl was admitted because of lower back pain and bowel constipation for several days. She was initially referred with the probable diagnosis of bilateral ovarian masses in an abdominal ultrasound. She had not attained menarche. There was no history of cyclic abdominal pain or urinary retention. The patient's secondary sexual characteristics were present. Physical examination revealed a distended abdomen, lower abdominal tenderness and a hypogastric mass. On pelvic examination, the hymen was found to be imperforate and was bulging forwards (figure 1). On rectal examination, a large mass was felt anteriorly. Abdominal ultrasound revealed a dilated vagina, suggestive of haematocolpos; a dilated uterus, suggestive of haematometra (figure 2) and bilateral pelvic cystic adnexal masses (figure 3; A-left, B-right). The patient was taken to the operating room and a cruciate incision was made over the hymen under general anaesthesia. Around $850 \mathrm{~mL}$ of dark, red,

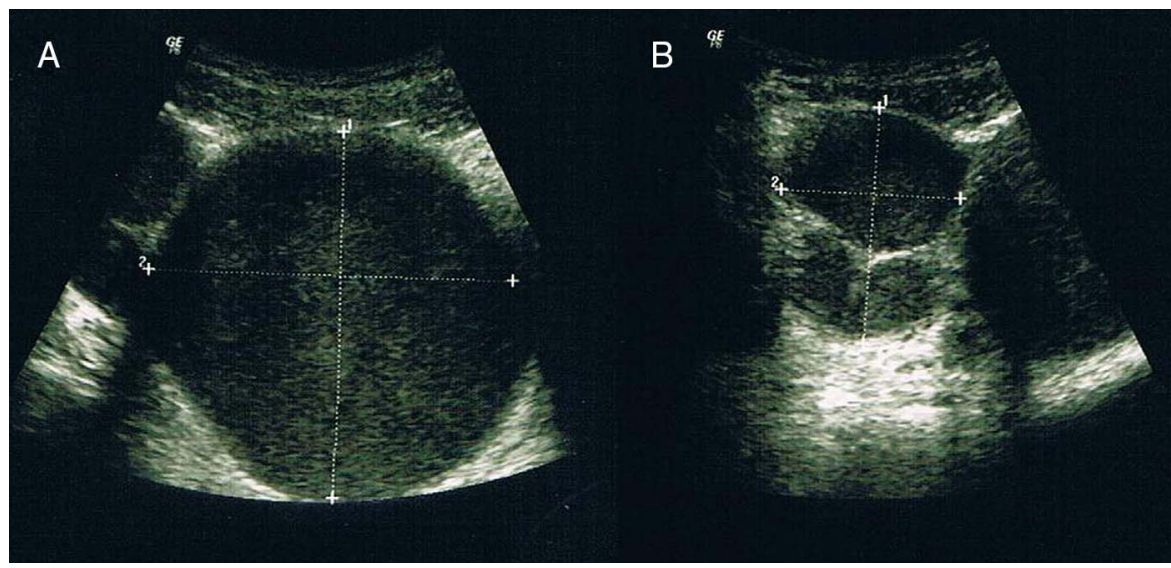

Figure 3 Ultrasound also showed bilateral pelvic cystic adnexal masses (on the left-A; and right ovary-B). 
tarry blood was drained. No other vaginal anatomic abnormality was found. The postoperative period was uneventful. A follow-up abdominal ultrasound, 9 months later, showed no abnormalities.

\section{Learning points}

- Imperforate hymen is a rare diagnosis, but should be considered when dealing with premenarcheal adolescent girls with back pain and pelvic masses.

- Difficult defecation (outflow obstruction due to compression) is a possible symptom and was present in this patient.
Contributors The authors (CC, CP and BR) contributed to concept and design, analysis and interpretation of the data, drafting and critical revision of the manuscript for important intellectual content and final approval of this article.

Competing interests None declared.

Patient consent Obtained.

Provenance and peer review Not commissioned; externally peer reviewed.

\section{REFERENCES}

1 Letts M, Haasbeek J. Hematocolpos as a cause of back pain in premenarchal adolescents. J Pediatr Orthop 1990;10:731-2.

2 Wang $\mathrm{W}$, Chen $\mathrm{MH}$, Yang $\mathrm{W}$, et al. Imperforate hymen presenting with chronic constipation and lumbago: report of one case. Acta Paediatr Taiwan 2004:45:340-2.

3 Dane C, Dane B, Erginbas M, et al. Imperforate hymen-a rare cause of abdominal pain: two cases and review of the literature. J Pediatr Adolesc Gynecol 2007;20:245-7.

Copyright 2015 BMJ Publishing Group. All rights reserved. For permission to reuse any of this content visit http://group.bmj.com/group/rights-licensing/permissions.

BMJ Case Report Fellows may re-use this article for personal use and teaching without any further permission.

Become a Fellow of BMJ Case Reports today and you can:

- Submit as many cases as you like

- Enjoy fast sympathetic peer review and rapid publication of accepted articles

- Access all the published articles

- Re-use any of the published material for personal use and teaching without further permission

For information on Institutional Fellowships contact consortiasales@bmjgroup.com

Visit casereports.bmj.com for more articles like this and to become a Fellow 